Geological Society, London, Special Publications Online First

\title{
Global Heritage Stone: Estremoz Marbles, Portugal
}

Luís Lopes and Ruben Martins

Geological Society, London, Special Publications, first published August 15, 2014; doi 10.1144/SP407.10

$\begin{array}{ll}\begin{array}{l}\text { Email alerting } \\ \text { service }\end{array} & \begin{array}{l}\text { click here to receive free e-mail alerts when } \\ \text { new articles cite this article }\end{array} \\ \begin{array}{l}\text { Permission } \\ \text { request }\end{array} & \begin{array}{l}\text { click here to seek permission to re-use all or } \\ \text { part of this article }\end{array} \\ \text { Subscribe } & \begin{array}{l}\text { click here to subscribe to Geological Society, } \\ \text { London, Special Publications or the Lyell } \\ \text { Collection }\end{array}\end{array}$

How to cite click here for further information about Online First and how to cite articles

\section{Notes}




\title{
Global Heritage Stone: Estremoz Marbles, Portugal
}

\author{
LUÍS LOPES ${ }^{1,2 *} \&$ RUBEN MARTINS ${ }^{1}$ \\ ${ }^{1}$ University of Évora, School of Sciences and Technology, Department of Geosciences, \\ Rua Romão Ramalho, 59, 7002554 Évora, Portugal \\ ${ }^{2}$ Geophysics Centre of Évora, Rua Romão Ramalho, 59, 7002554 Évora, Portugal \\ *Corresponding author (e-mail: lopes@uevora.pt)
}

\begin{abstract}
Paleozoic calcitic marbles are found in the Estremoz Anticline, Ossa-Morena Zone (Southern Branch of the European Variscides in Portugal). This $40 \mathrm{~km} \mathrm{NW-SE} \mathrm{structure} \mathrm{presents}$ outcrop continuity and intense mining activity since the Roman Period. The structure has a Precambrian core and the younger rocks are from the Devonian Period. The marbles occupy an intermediate stratigraphic position in the Cambrian age Volcano Sedimentary Sequence. The Variscan Orogeny had two pulses with different intensities under ductile and brittle tension fields. The Alpine Cycle also caused more fracturing of the marbles. The geological features imprinted in the marbles are beautiful aesthetic patterns highlighted when used as dimension stone.

Since the Roman period, pieces of art made with Estremoz Marble were exported abroad and can be found in museums and archaeological sites throughout Europe and North Africa countries. Present day, Estremoz Marble objects can be found all over the world.

The very rich marble based heritage is omnipresent in cities, and the countryside is marked by intense mining activity side by side with rural industries; therefore the region has unique characteristics allowing the development of integrated industrial tourism routes, promoting sustainable development of industrial, scientific and technological cultural opportunities.

The historical and widespread application of these marbles in national and international monuments, some of them already part of the UNESCO World Heritage Sites, is a condition to propose them as Global Heritage Stone Resource for their international recognition.
\end{abstract}

Constituting a symbol of economic strength, good taste and distinction, it can be said that, virtually, there is no city in Portugal where Estremoz Marble has not, somehow, been used in both small works of art or utilitarian objects as public monuments and in private homes. It is estimated there would be hundreds of thousands of buildings that have used Estremoz Marble. Historically documented, usage dates back to the fourth century BC (Alarcão \& Tavares 1989; Maciel \& Coutinho 1990; Cabral et al. 1992) and extends to where currently, owing to the global commercial trade, Estremoz Marble can be found all over the World.

On the Sistema de Informação para o Património Arquitectónio (SIPA) webpage (Information System for Architectural Heritage, which is a system of information and documentation of Portuguese architectural, urban and landscape heritage of Portuguese origin managed by the Institute for Housing and Urban Renewal (IP - IHRU), http:// www.monumentos.pt), 179 national monuments are referenced where Estremoz Marble has been used. By itself, this fact constitutes an indicator of the marble's importance in the history of Portugal and certifies its value as a Global Heritage Stone Resource to be preserved. This long-term intense use is a sign of its high quality, the only way to justify the demand that has continued for more than 25 centuries; otherwise, demand would have ceased. Nowadays business associations and Portuguese dimension stone companies have made a huge effort towards the promotion and marketing that has led to the creation of the brand 'Stone PT' (http:// stone-pt.com/en/). In addition to other marbles, this brand also includes other Portuguese dimension stones. High levels of quality, certification, verification and management are associated with this brand. In fact, besides the Estremoz Marble, Portugal has mining units of ornamental rocks throughout its territory (i.e. Carvalho et al. 2013 for more detailed information). The northern part of the country is rich in igneous rocks, particularly granites, while Jurassic microcrystalline limestones are concentrated in the Maciço Calcário Estremenho (central western part of the country). With huge relevance during in the 15 th -18 th centuries in the Portuguese maritime expansion and the rebuilding of Lisbon after the 1755 earthquake, some varieties of Cretaceous 'Lioz' limestone were exploited near Sintra (Pêro Pinheiro, Negrais, Montemor, Lameiras) north of Lisbon. Nowadays there are a few quarries in these limestones. There are also considerable reserves of Jurassic limestone breccias in Algarve (S. Brás de Alportel - Tavira, South Portugal), as well as a kind of Cretaceous nepheline syenite, unique in the world, exploited in Serra de Monchique 